\title{
ANALYSIS OF THE EFFECT OF CAR, LDR AND NPL ON THE DISTRIBUTION OF MSME CREDITS ON COMMERCIAL BANKS IN INDONESIA PERIOD 2014-2017
}

\author{
Lawe Anasta \& Suharmadi \\ Economics Faculty, Universitas Mercu Buana
}

\begin{abstract}
This study was to determine the effect of Capital Adequacy Ratio (CAR), Loan to Deposit Ratio (LDR), and Non-Performing Loans (NPL) to the lending of Micro, Small and Medium Enterprises (MSMEs). The object of this research is commercial banks listed on the IDX in the 2014-2017 period. This research was conducted on 124 public banks listed on the IDX at the vulnerable time 2014-2017 using a quantitative descriptive approach. Therefore the data analysis used is statistical analysis in the form of multiple linear regression tests. The results of this study indicate that partially and simultaneously the variable CAR, LDR and NPL have an effect on MSME lending to commercial banks listed on the IDX in the 2014-2017 period. This is evidenced from the results of the simultaneous test ( $\mathrm{F}$ test) and the partial test results $(\mathrm{t}$ test) also show significant values of the three independent variables that support the hypothesis. Therefore the results of the test from this study state that there is a simultaneous influence between the CAR, LDR and NPL variables on MSME lending to commercial banks found on the IDX in the 2014-2017 period.
\end{abstract}

Keywords: Capital Adequacy Ratio (CAR), Loan to Deposit Ratio (LDR), Non-Performing Loans (NPL), MSMEs, credit

DOI: $10.7176 / \mathrm{JRDM} / 61-07$

Publication date: November $30^{\text {th }} 2019$

\section{INTRODUCTION}

MSMEs (Micro, Small and Medium Enterprises) are business groups which often use their resources from the agriculture, plantation, livestock and trade sectors. This MSME is a business group that has advantages in terms of the absorption of its large workforce, so that it can help the equity process which is part of the country's economic development (Anggraini and Hakim, 2013).

According to Soedarto (2004) Capital Adequacy Ratio (CAR) has a positive and significant effect on bank credit, as well as research conducted by Budiawan (2008). The high CAR indicates the better the ability of the bank to bear the risk of any risky credit / productive assets. If the CAR value is high, the bank is able to finance operational activities and contribute significantly to profitability. A high CAR indicates that a bank has a large capital, the higher the CAR the greater the credit disbursed. Conversely, a low CAR indicates that banks do not have sufficient capital for lending. (Agus Murdiyanto, 2014)

Non-Performing Loans (NPL) is a ratio used to measure a bank's ability to cover the risk of failure to repay loans by debtors (Darmawan, 2004). NPL reflects credit risk, the higher the level of NPL, the greater the credit risk borne by the bank (Ali, 2004). As a result of the high NPL, banks must provide greater reserves, so that in the end the bank's capital is eroded. Even though the amount of capital greatly influences the amount of credit expansion. The amount of NPL is one of the causes of the difficulty of banks in lending (Sentausa, 2009). The high NPL can affect the bank's policy in channeling its loans, namely banks become more careful. Because banks that continue to provide credit when the NPL is high means that the bank includes risk taken. In line with the research conducted by Meydianawathi (2006) that NPL has a negative but significant effect on bank lending to the MSME sector in Indonesia where the high NPL of investment credit has caused the supply of credit to the MSME sector to be reduced. This result is not the same as the results of a study conducted by Francisca and Hasan Sakti Siregar (2008) which showed that NPLs cannot be used to predict credit volumes because the results of the partial tests show negative but not significant effects on the volume of loans offered. Another case with the testing of Warjiyo (2006) which states that the influence of a positive NPL indicates the absence of caution in the behavior of credit offers by banks. Juda Agung (2001) stated that the high losses due to NPLs caused banks to become risk averse so that credit growth was slow.

The differences in the results of the above research regarding the effect of NPL on the amount of working capital loans channeled also occur in the facts in the field. Bank Swadesi in 2005 and 2006 had NPL values of 2.08\% 
and 5.92\%. While the amount of loans disbursed in 2005 and 2006 was 344.31 billion rupiahs and 350.7 billion rupiahs. What happened in 2005-2006 was the value of NPL increased by $184.62 \%$ and followed by an increase in the number of working capital loans of $1.86 \%$. Which means that the NPL had a positive effect on the amount of

credit.

\section{LITERATURE, LOGICAL FRAMEWORK AND HYPOTHESIS}

Jensen and Meckling (1976) describe agency relationships in agency theory that a company is a collection of contracts (nexus of contract) between owners of economic resources (principal 1) and the manager (agent) who manages the use and control of these resources. According to Meisser, et al., (2006: 7) this agency relationship results in two problems, namely: (a) the occurrence of asymmetric information (information asymmetry), where management generally has more information about actual financial position and operating position of the entity; and (b) the occurrence of conflict of interest due to unequal objectives, where management does not always act in accordance with the interests of the owner.

The essence of Agency Theory or agency theory is the right contract design to harmonize the interests of principals and agents in the event of a conflict interests (Scott, 1997). Based on this in lending where banks become agents in channeling loans and bank owners are principals sometimes have conflicts of interest in terms of credit allocation where owners have an interest in getting maximum return and management has other interests in allocating credit to improve performance so that securing its position and with existing data and information can be analyzed the influence of variables in lending in the MSME sector whether there is maximum credit distribution to the MSME sector in accordance with the interests of the owner, therefore it is necessary to design a contract that accommodates the interests of the owner and has been agreed with management.

\section{LOAN AND CREDIT OF MSME}

Human needs always increase, while capabilities and tools to fulfill them are limited. In order to fulfill these needs, one can be facilitated to fulfill it by way of being assisted from the aspect of capital in the form of credit.

\section{CAPITAL ADEQUACY RATIO (CAR)}

In conducting credit distribution, management should pay attention to regulations relating to the assessment of bank soundness (Pandia, 2014: 173). One of the assessments of bank soundness is CAR (Capital Adequacy Ratio). For banks, capital is an important factor for business development and maintaining the possibility of risk, one of the risks that may arise is the risk of bad credit. CAR shows the bank's capital adequacy in bearing the risks that might arise due to bank operational activities (Sari, 2013). Capital Adequacy Ratio (CAR) is a capital ratio that shows the ability of banks to provide funds for business development needs and accommodate the risk of loss of funds caused by bank operations (Ali, 2004). The higher the CAR, the greater the financial resources that can be used to anticipate the potential losses caused by lending. In other words the value of CAR will increase banking confidence in channeling credit. With CAR above $20 \%$, banks can spur credit growth of up to 20-25 percent a year (Wibowo, 2009).

\section{Logical Framework}

MSME lending is expected to help capital problems experienced by MSMEs, MSMEs as a sustainable economic blood towards financial turmoil both domestically and internationally, there is a fluctuating development of lending to MSMEs, therefore researchers are looking for factors that influence lending to MSMEs in terms of credit offerings. From commercial banks, some of these factors are Capital Adequacy Ratio (CAR), Loan to Deposit Ratio (LDR), and Non-Performing Loans (NPL). 


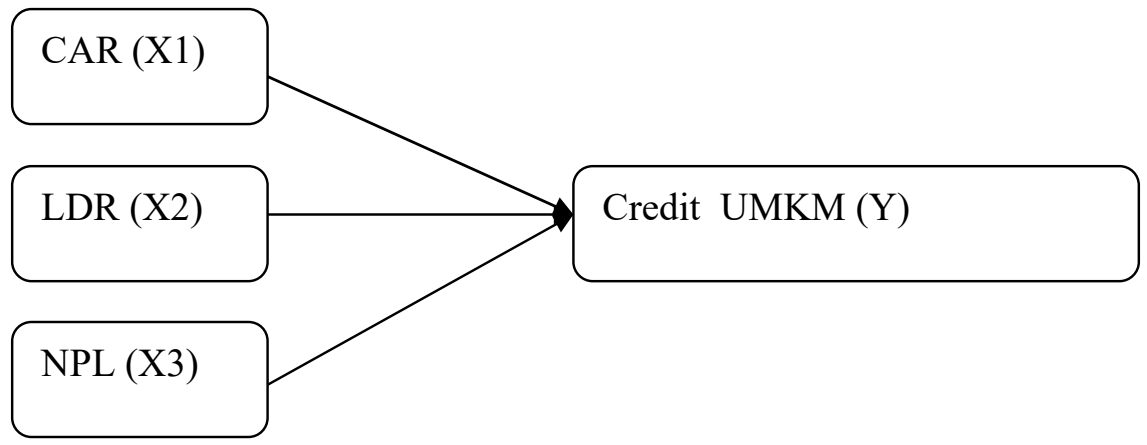

\author{
Hypothesis \\ H1 = CAR (Capital Adequacy Ratio) has an influence on distribution \\ MSME loans at commercial banks in Indonesia. \\ H2 = LDR (Loan Deposit Ratio) has an influence on distribution \\ MSME loans at commercial banks in Indonesia. \\ H3 = NPL (Non-Performing Loan) has an influence on distribution \\ MSME loans at commercial banks in Indonesia. \\ H4 = CAR, LDR and NPL together have an influence on Distribution \\ MSME loans at commercial banks in Indonesia.
}

\title{
RESEARCH METHODS
}

Time and Place of Research

the study was conducted in Indonesia with data obtained from the Financial Services Authority accessed from www.ojk.go.id, and from Bank Indonesia accessed from www.bi.go.id, financial report data for commercial banks registered with Indonesian securities from the period 2014 - 2017 accessed from March to June 2017.

\section{Research design}

According to Nur Indriantoro and Bambang Supomo (2002: 249), the definition of research design is as follows:

"Research design is the main design of research that states the methods and procedures used by researchers in the selection, collection, and analysis of data."

In addition, this study also uses a comparative causal research design. Nazir stated comparative research is descriptive research that wants to find answers fundamentally about causation, by analyzing the factors that cause or the emergence of a particular phenomenon.

Definition and Operationalization of Variables According to Sugiyono (2014: 59), the research variable is an attribute or value of a person, object or activity that has certain variables set by the researcher to be studied and drawn conclusions. In this study, the variable used is the number of working capital loans as the dependent variable (Y). Whereas used for independent variable is Capital Adequacy Ratio (X1), Loan to Deposit Ratio (X2), Non-Performing Loan (X3).

\section{Research Population and Samples}

Population is a generalization area consisting of subjects or objects that have certain qualities and characteristics set by researchers to be studied for later conclusions drawn (Sugiyono, 2010: 115). The population used in this study is the annual financial statements of commercial banks registered with the Bank. Indonesia (BI) and the Financial Services Authority (OJK).

Samples are part of the number and characteristics possessed by the population (Sugiyono, 2010: 115). The samples taken are the annual financial statements of Bank Indonesia and the Financial Services Authority for 4 periods, namely the period 2014 - 2017.The sampling technique used in this study was purposive sampling. In 
this type of sampling technique, the sample is chosen to represent the population, the sample chosen is according to the general rule that sampling is required at least 4 periods for each independent.

\section{RESEARCH RESULTS AND DISCUSSION}

\section{Descriptive statistics}

Descriptive statistical analysis in this study will show the minimum, maximum, mean and standard deviations of each variable. The Minimum Value is the lowest value for each variable, while the maximum value is the highest value for each variable in the study. Mean value is the average value of each variable studied. Standard deviation is the distribution of data used in research that reflects the heterogeneous or homogeneous data that is fluctuating.

Table 4.1. Statistic descriptive

Descriptive Statistics

\begin{tabular}{lrrrrr}
\hline & \multicolumn{1}{c}{ CAR } & \multicolumn{1}{c}{ LDR } & \multicolumn{1}{c}{ NPL } & \multicolumn{1}{c}{ UMKM } & Valid N () \\
$\mathrm{N}$ & 124 & 124 & 124 & 124 & 124 \\
Minimum & .0802 & .5239 & .0000 & 120.658 .000 & \\
Maximum & .2791 & 1.4072 & .0545 & 393.968 .167 .000 & \\
Mean & .193227 & .835848 & .014722 & 22.770 .445 .969 .26 & \\
Std. Deviation & .1321773 & .1665095 & .0122382 & 59.606 .290 .059 & \\
\hline
\end{tabular}

\section{Classical Assumption Test Results}

Normality test

this test aims to test in the regression model, the residual confounding variable has a normal distribution. How to detect residuals has a normal distribution or not, namely by Skewness and Kurtosis Test and graph analysis.

Based on table 4.2, Zskew and Zkurt values can be calculated as follows:

Result of Zskew $=0 \mathrm{~S} /(\sqrt{6} / \mathrm{N})$

$=0.369 /(\sqrt{ } 6 / 124)=1,677$

Zkurt value $=\mathrm{K} /(\sqrt{24} / \mathrm{N})$

$=-0.722 /(\sqrt{ } 24 / 124)=-1.64$

Normality Test Value

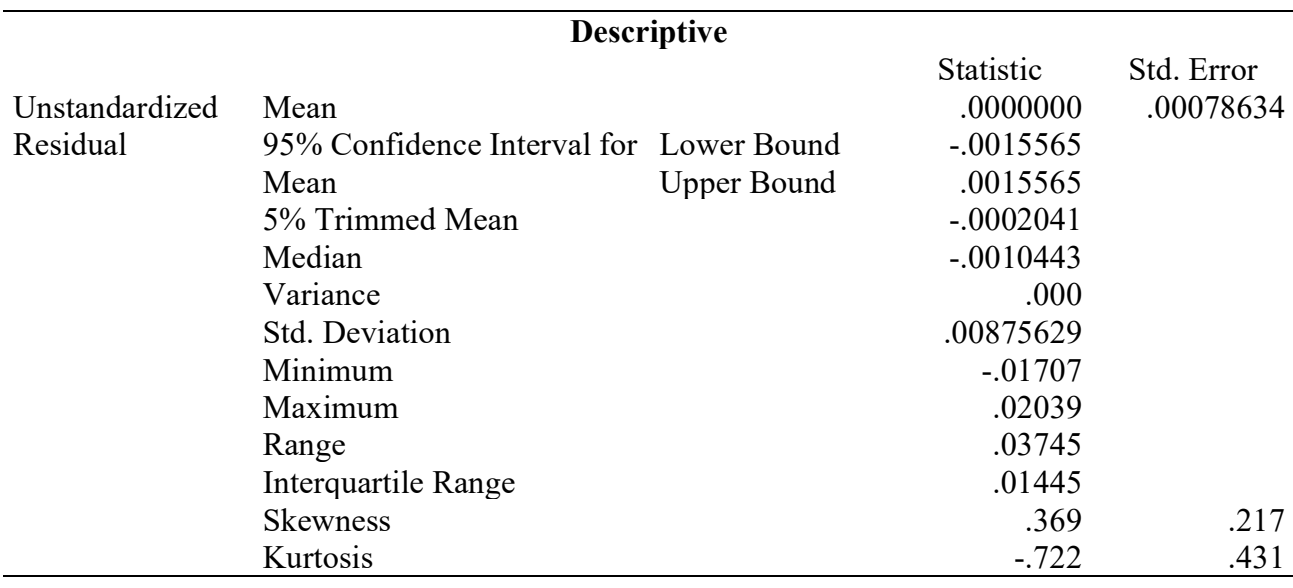

Because the results of Zskew and Zkurt are within the range -1.96 to +1.96 , the data is normally distributed. This normal data can also be seen in the normal plot graph in Figure 4.1. From the curve analysis it can be seen that the data spreads around the diagram and follows the regression model so that it can be concluded that the data processed is normally distributed data so that the normality test is fulfilled. 


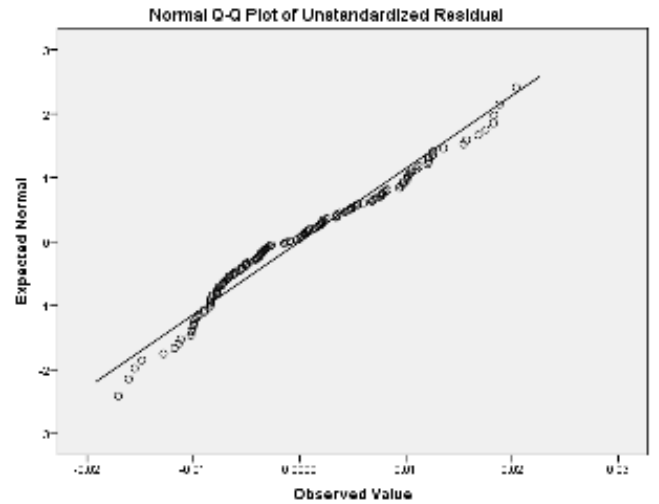

Figure 4.1. Normal the data plot is normally distributedSource: Data Results, 2017

Table 4.3. VIF Value for Testing Multicollinearity

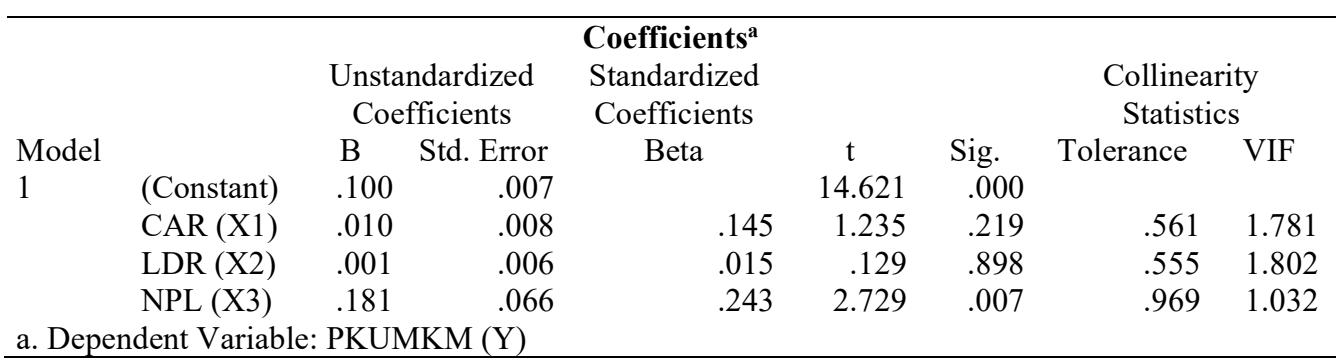

Figure 4.2 shows that there is no heteroscedasticity because there is no clear pattern and the points spread above and below the number 0 on the $\mathrm{Y}$ axis. So that it can be said that heteroscedasticity tests are fulfilled.

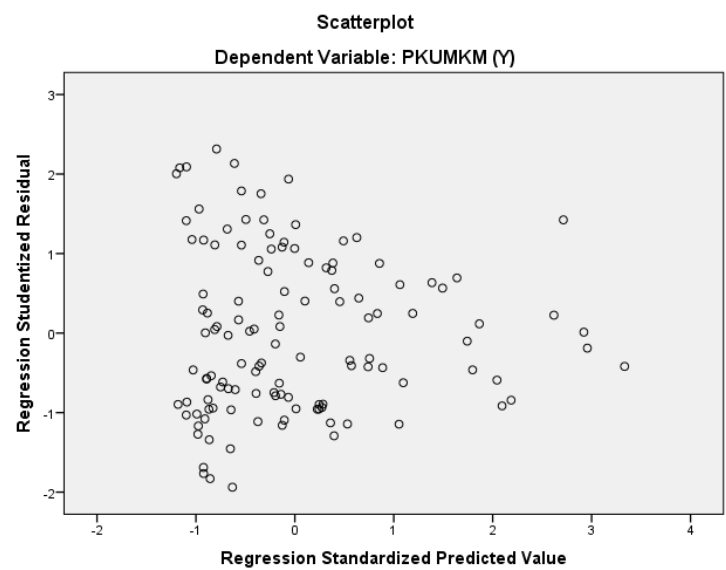

Figure 4.2. Scatterplot Graph Heteroskedisticity Test Source: Processed data

Table 4.4. Durbin-Watson value for Autocorrelation test

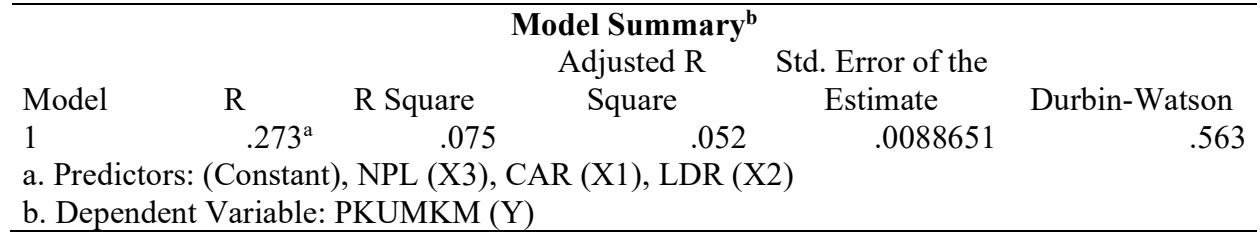


The existence of autocorrelation in linear regression (Ordinary Least Squares) causes sample variance cannot describe population variance, the resulting regression model cannot be used to predict the value of variables not independent of certain variable values, the regression coefficient obtained is less accurate. This autocorrelation problem often occurs in linear regression using time-series data. To overcome the problem of autocorrelation, the Cochrane-Orcutt method was transformed. After the autocorrelation coefficient is known, the next step is to transform. Then from the transformed data, repeat detection is performed to detect the presence or absence of autocorrelation. If there is still autocorrelation in the transformed data, the transformation will be repeated until there is no autocorrelation. After obtaining avoidable data and autocorrelation, the next step applies the Ordinary Least Squares (OLS) method to determine the regression coefficients. From calculations using the CochraneOrcutt method using the SPSS program, the rho coefficient value (p) is obtained at 0.719 and the second step is 0.135 , so the autocorrelation value becomes like table 4.5 .

Table 4.5. The Durbin-Watson value after the Cochrane-Orcutt transformation is carried out

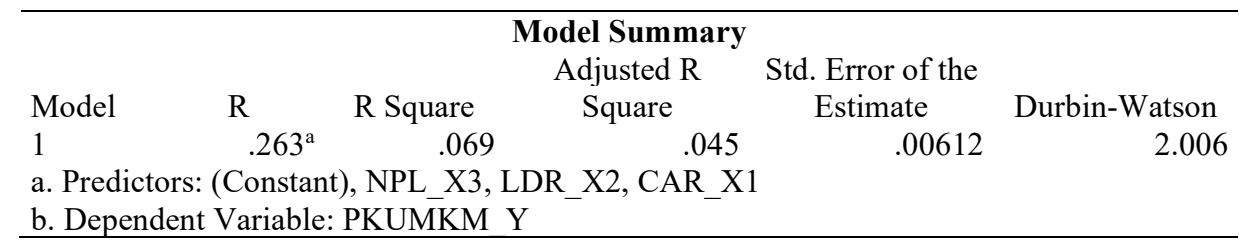

Hypothesis Test Results

Hypothesis testing is done by statistical models Multiple regression analysis is a statistical model by identifying and analyzing the relationships between dependent variables and independent variables.

Table 4.6. Table of Coefficients

\begin{tabular}{|c|c|c|c|c|c|c|c|c|}
\hline \multicolumn{9}{|c|}{ Coefficients ${ }^{\mathbf{a}}$} \\
\hline \multirow[b]{2}{*}{ Model } & \multirow[b]{3}{*}{ (Constant) } & \multicolumn{2}{|c|}{$\begin{array}{l}\text { Unstandardized } \\
\text { Coefficients }\end{array}$} & \multirow{2}{*}{$\begin{array}{l}\text { Standardized } \\
\text { Coefficients } \\
\text { Beta }\end{array}$} & \multirow{2}{*}{$\mathrm{t}$} & \multirow{2}{*}{ Sig. } & \multicolumn{2}{|c|}{$\begin{array}{c}\text { Collinearity } \\
\text { Statistics }\end{array}$} \\
\hline & & $\mathrm{B}$ & Std. Error & & & & Tolerance & VIF \\
\hline 1 & & .024 & .001 & & 18.483 & .000 & & \\
\hline & CAR_X1 & .005 & .007 & .074 & .742 & .459 & .798 & 1.253 \\
\hline & LDR_X2 & .003 & .005 & .053 & .536 & .593 & .817 & 1.224 \\
\hline & NPL_X3 & .140 & .047 & .268 & 2.951 & .004 & .955 & 1.047 \\
\hline a. Depe & dent $\bar{V}$ ariab & KUMK & M Y & & & & & \\
\hline
\end{tabular}

Table 4.7 Hypothesis test Variable X to Variabel Y

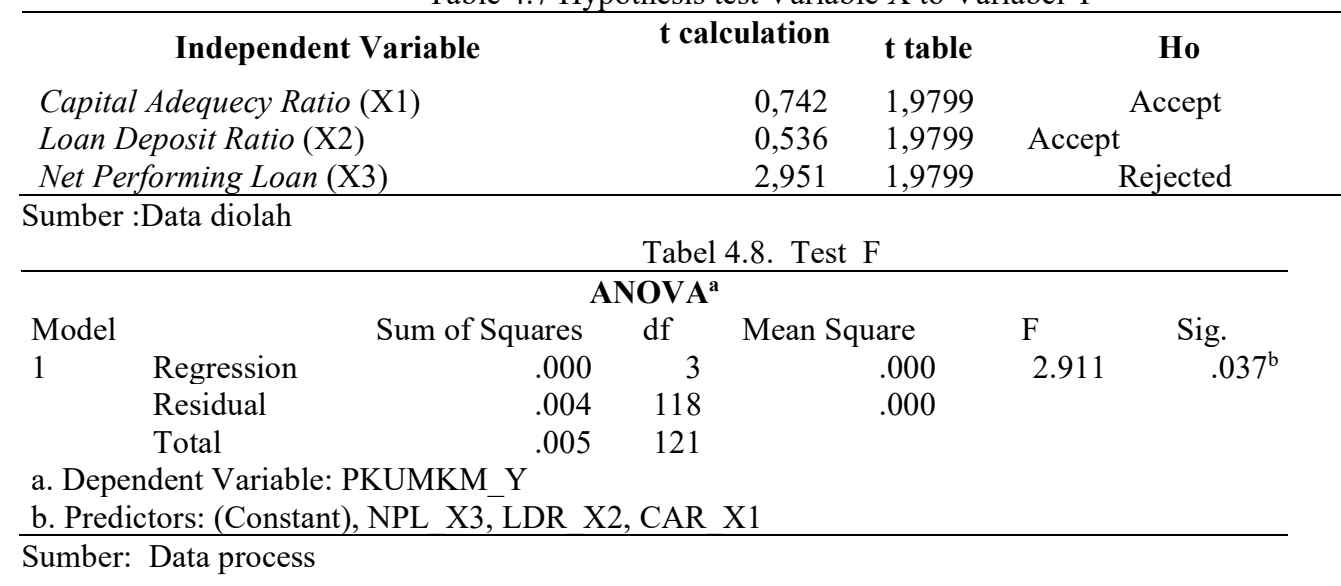


Table 4.9. Determinasi analysis $\left(\mathrm{R}^{2}\right)$

\begin{tabular}{|c|c|c|c|c|c|}
\hline \multicolumn{6}{|c|}{ Model Summary ${ }^{b}$} \\
\hline Model & $\mathrm{R}$ & R Square & $\begin{array}{l}\text { Adjusted R } \\
\text { Square }\end{array}$ & $\begin{array}{l}\text { Std. Error of the } \\
\text { Estimate }\end{array}$ & Durbin-Watson \\
\hline 1 & $.263^{\mathrm{a}}$ & .069 & .045 & .00612 & 2.006 \\
\hline $\begin{array}{l}\text { a. Predi } \\
\text { b. Depe }\end{array}$ & $\begin{array}{l}\text { Constar } \\
\text { Variable }\end{array}$ & $\begin{array}{l}\text {, NPL_X3, } \\
\text { PKUMKM }\end{array}$ & R_X2,CAR_X1 & & \\
\hline
\end{tabular}

Sumber: Data process

\section{DISCUSSION}

Effect of CAR on UMKM Loan Distribution (PKUMKM)

The t-test results show that the variable Capital Adequacy Ratio (X1) has a t-count value of 0.742 that is greater than -1.9799 and smaller than $1.9799(-1.9799<0.742<1.9799)$. So that Ho is accepted and Ha is rejected, then Capital Adequecy Ratio does not significantly influence MSME Credit Distribution in banks in Indonesia.

The Influence of LDR on MSME Credit Distribution (PKUMKM)

Variable Loan Deposite Ratio (X2) has a value of $\mathrm{t}$ equal to 0.536 which is greater than -1.9799 and smaller than $1.9799(-1.9799<0.536<1.9799)$. So that Ho is accepted and Ha is rejected, then the Loan Deposit Ratio does not significantly influence MSME Credit Distribution in banks in Indonesia.

Influence of NPL on UMKM Loan Distribution (PKUMKM)

The Net Performing Loan variable (X3) has a t value of 2.951 which is greater than 1.9799 (2.951> 1.9799). So that $\mathrm{Ho}$ is rejected and $\mathrm{Ha}$ is accepted, then the Net Performing Loan has a significant effect on MSME Credit Distribution in banks in Indonesia.

Effect of CAR, LDR and NPL on MSME Credit Distribution (PKUMKM)

$\mathrm{X}$ variable (CAR, LDR and NPL) simultaneously has an F value of 2.911 with a significance value of 0.037 which is smaller than $0.05(0.037>0.05)$. So that Ho is rejected and Ha is accepted, then the variable X (CAR, LDR and NPL) together has a significant effect on MSME Credit Distribution in banks in Indonesia.

\section{CONCLUSIONS AND SUGGESTIONS \\ Conclusion}

Based on research and discussion, the conclusions of this study are:

1. The results of the $t$ test show that the Capital Adequacy Ratio (CAR) does not significantly influence the amount of MSME Credit Distribution in Indonesian banks listed on the Indonesia Stock Exchange in 2014-2017 2. The results of the $t$ test show that the Loan Deposit Ratio (LDR) does not significantly influence the amount of MSME Loan Distribution in Indonesian banks listed on the Indonesia Stock Exchange in $2014-2017$

3. The t-test results show that the Net Performing Loan (NPL) significantly influences the amount of MSME Loan Distribution in Indonesian banks listed on the Indonesia Stock Exchange in 2014 - 2017.

4. The F test results indicate that the Capital Adequacy Ratio (CAR), Loan Deposit Ratio (LDR) and Net Performing Loans (NPL) together have a significant effect on the number of MSME Loan Disbursements in Indonesian banks listed on the Indonesia Stock Exchange in the year 2014 - 2017.

In this paper, there are some limitations that limit this research, including:

1. Research is only carried out in the short year range, which is only 4 years from $2014-2017$.

2. This research has not divided banks based on bank size or size, that is, banks have small assets and banks have large assets.

3. A fairly disturbing limitation is the lack of correlation between the variables studied and the small representation of the independent variables examined in influencing the dependent variable.

\section{Suggestion}

1. Increase the number of samples by increasing the number of years from each bank.

2. Dividing the banks studied based on the size or size of each bank so that banks with small assets are separate from banks that have large assets.

3. Adding an independent variable that will enlarge the relationship between the independent variable and the dependent variable, so what variables will have the greatest influence.

4. For banking companies to pay attention to the level of CAR, LDR and NPL related to the distribution of credit funds to MSMEs. 


\section{REFERENCES}

Achmad, Tarmizi \& Willyanto K.Kusumo,2003,Analisis Rasio-Rasio Keuangan Sebagai Indikator dalam Memprediksi Potensi Kebangkrutan Perbankan di Indonesia, Media Ekonomi dan Bisnis, Vol.XV, No.1,Juni.

Adnan, A., Ridwan, R. dan Fildzah, F. 2016. Pengaruh Ukuran Bank, Dana Pihak Ketiga, Capital Adequacy Ratio, dan Loan To Deposit Ratio Terhadap Penyaluran Kredit Pada Perusahaan Perbankan yang Terdaftar Di Bursa Efek Indonesia Tahun 2011-2017.Jurnal Dinamika Akuntansi dan Bisnis,3(2), pp.49-64.

Agnes Sawir.2001.Analisis Kinerja Keuangan dan Perencanaan Keuangan Perusahaan.Jakarta:PT Gramedia Pustaka Utama.

Agung, Juda.dkk. 2001. Credit Crunch di Indonesia Setelah Krisis (Fakta,Penyebab dan Implikasi Kebijakan). Jakarta: Bank Indonesia, Pusat Studi dan Kebanksentralan.

Agus Murdiyanto.2014.Faktor-Faktor Yang Berpengaruh Dalam Penentuan Penyaluran Kredit Perbankan Studi Pada Bank Umum Di Indonesia Periode Tahun 2006-2011.Proceedings of conference in business, accounting and manajement.Vol.1 No. 1 December 2014.

Ali, Mashud. (2004).Asset Liability Management : Menyiasati Risiko Pasar dan Risiko Operasional.Jakarta : PT. Gramedia.

Almilia,L.S. dan Winny Herdiningtyas, 2005.Analisis Rasio CAMEL Terhadap Prediksi Kondisi Bermasalah Pada Lembaga Perbankan Periode 2000-2002,Jurnal Akuntansi dan Keuangan,Vol. 7 No.2 Nopember 2005

Amalia Yuliana.2014. Pengaruh LDR, CAR, ROA, dan NPL Terhadap Penyaluran Kredit: Pada Bank Umum Di Indonesia Periode 2008-2013. Jurnal Dinamika Manajemen. Volume II No 3.

Anggraini, Dewi dan Syahrir Hakim Nasution.2013. Peran Kredit Usaha Rakyat (KUR) Bagi Pembangunan UMKM di Kota Medan (Studi Kasus Bank BRI)

Budiawan. 2008. Analisis Faktor-faktor yang Mempengaruhi Penyaluran Kredit Pada BPR (Studi Kasus pada BPR di Wilayah Kerja BI Banjarmasin). Tesis Program Magister Manajemen Universitas Diponegoro Semarang.

Budisantoso,Totok dan Nuritomo,2014, Bank dan Lembaga Keuangan Lainnya,Edisi 3,Jakarta:Salemba Empat, Darmawan,Komang.(2004).Analisis Rasio-rasio Bank.Info Bank.Juli 18-21.

Darmawi, Herman. 2011. Manajemen Perbankan. Jakarta: Bumi Aksara.

Dendawijaya, Lukman. 2005. Manajemen Perbankan. Bogor: Ghalia Indonesia.

Eisenhardt, Kathleem.(1989). Agency Theory: An Assesment and Review. Academy of Management Review.14.Hal 57-74.

Febrianto, Dwi Fajar \& Dul Muid. Analisis Pengaruh Dana Pihak Ketiga, LDR, NPL, CAR, ROA, dan BOPO terhadap Jumlah Penyaluran Kredit (Studi pada Bank Umum yang Terdaftar Di Bursa Efek Indonesia Periode Tahun 2009-2014). Dipenogoro Journal of Accounting, 2 (4): 1-11.

Ghozali,Imam dan Arfan Ikhsan.(2006).Metodologi Penelitian Untuk Akuntansi dan Manajemen.Medan: PT. Madju Depan Cita.

Harlen Butar-Butar dan Aris Budi Setyawan,”Analisis Perbandingan Tingkat Kolektibilitas Kredit Pada Bank Pembangunan Daerah Di Pulau Jawa Dan Luar Pulau Jawa Desember 2002 Sampai Dengan Desember 2006”.Jurnal Ekonomi,Fakultas ekonomi,Universitas Widyatama, Bandung.

Harmanta dan Ekananda.(2005)."Disintermediasi Fungsi Perbankan di Indonesia Pasca Krisis 1997:Faktor Permintaan atau Penawaran Kredit”. Buletin Ekonomi Moneter dan Perbankan (Volume 8 No. 1, Juni 2005).

Hasibuan, Malayu S.P. 2011. Dasar-dasar Perbankan. Jakarta: Bumi Aksara.

Jensen, M. C and Meckling, W.H. 1976. Theory of the Firm : Managerial Behavior, Agency Costs and Ownership Structure.Journal of Financial Economics, Oktober, 1976,V.3,No.4,pp.305-360.Avalaible from:http://papers.ssrn.com

Juli Irmayanto, dkk, 2002, Bank dan Lembaga Keuangan,Universitas Trisakti,Jakarta.

Kasmir. (2014). Bank dan Lembaga Keuangan Lainnya. Edisi Revisi, Cetakan keempatbelas, PT. RajaGrafindo Persada, Jakarta.

Kasmir. (2014). Dasar-Dasar Perbankan. Edisi Revisi, Cetakan ke duabelas, PT. RajaGrafindo Persada, Jakarta.

Kasmir. (2003). Dasar-Dasar Perbankan. Cetakan Kedua, PT.RajaGrafindo Persada, Jakarta.

Kuncoro, Mudrajat dan Suhardjono.2002.Manajemen Perbankan:Teori dan Aplikasi. Edisi Pertama.Yogyakarta:BPFE.

Messier,W.F.,Glover,S.M.,dan Prawitt,D.F.(2006).Auditing and Assurance Services a Systematic Approach.Edisi Keempat.Penerbit Salemba 4. McGraw-Hill Irwin.Singapore 
Meydianawathi, Luh Gede.(2006).Analisis Perilaku Penawaran Kredit Perbankan Kepada Sektor UMKM di Indonesia (2002-2006).Universitas Udayana Denpasar: Buletin Studi Ekonomi. Volume 12 Nomor 2 Tahun 2006

Rachma Gita, Syachrudin Deni, 2017, Profita, Pengaruh Leverage Keuangan terhadap Tingkat Aktivitas Investasi Bank (Studi Kasus Perbankan yang Terdaftar di Bursa Efek Indonesia Periode 2012-2015)

Republik Indonesia. Undang-Undang Republik Indonesia Nomor 10 Tahun 1998 Tentang Perubahan atas Undang-Undang Nomor 7 Tahun 1992 Tentang Perbankan

Pandia, Frianto.(2014).Manajemen Dana dan Kesehetan Bank.Jakarta: Rineka Cipta

Republik Indonesia. Undang-Undang Republik Indonesia Nomor 20 Tahun 2008 Tentang Usaha Mikro, Kecil, dan Menengah.

Rivai, Veithzal et al. 2013. Commercial Bank Management; Manajemen Perbankan; dari Teori ke Praktik. Jakarta: PT Raja Grafindo Persada.

Sanusi, Anwar. 2011. Metodelogi Penelitian Bisnis. Jakarta: Salemba Empat.

Sari, Greydi Normala. 2013. Faktor-faktor yang Mempengaruhi Penyaluran Kredit Bank Umum di Indonesia (Periode 2008.1 - 2014.2). Jurnal EMBA, 1 (3): 931-941.

Scott,William R,1997, Financial Accounting Theory, International Edition,New Jersey : Prentice Hall,Inc.

Sentausa,Sentot A.2009.Perbankan Minta BI Mempermudah Aturan. Kompas.com. Selasa 29 September 2017. Soedarto.Moch, 2004, Analisis Faktor-faktor yang Mempengaruhi Penyaluran Kredit Pada Bank Perkreditan Rakyat (Studi Kasus pada BPR Wilayah Kerja BI Semarang). TESIS Programpascasarjana Magister Manajemen UNDIP.

Susilo, Sri.Y., Triandaru. Sigit, dan A. Totok Budi Santoso.(2000).Bank dan Lembaga Keuangan Lain. Jakarta: Salemba Empat.

Syahyunan, 2002, Analisis Kualitas Aktiva Produktif Sebagai Salah Satu Alat Ukur Kesehatan Bank, Jurnal Perbankan, di akses 19 Maret 2008.

Wibowo, Dradjad H.2009.Bank Sulit Pacu Kredit Pada 2010. Kompas.com. Rabu 21 Oktober 2017. 